\title{
Recent Genotypes of Phytophthora infestans in the Eastern United States Reveal Clonal Populations and Reappearance of Mefenoxam Sensitivity
}

\author{
Chia-Hui Hu, Department of Plant Pathology, North Carolina State University, Raleigh, 27695; Frances G. Perez, United States \\ Department of Agriculture-Agricultural Research Service (USDA-ARS) PSI-GIFVL, BARC-West, Beltsville, MD, 20705; \\ Ryan Donahoo, University of Florida, Florida IFAS-SWFREC, Immokalee, 34142; Adele McLeod, Department of Plant Pathology, \\ University of Stellenbosch, Stellenbosch, South Africa; Kevin Myers, Department of Plant Pathology, Cornell University, Ithaca, NY; \\ Kelly Ivors, Department of Plant Pathology, North Carolina State University; Gary Secor, Department of Plant Pathology, North \\ Dakota State University, Fargo, 58108-6050; Pamela D. Roberts, University of Florida, Florida IFAS-SWFREC; Kenneth L. Deahl, \\ USDA-ARS PSI-GIFVL, BARC-West; William E. Fry, Department of Plant Pathology, Cornell University; and Jean B. Ristaino, \\ Department of Plant Pathology, North Carolina State University
}

\begin{abstract}
Hu, C.-H., Perez, F. G., Donahoo, R., McLeod, A., Myers, K., Ivors, K., Secor, G., Roberts, P. D., Deahl, K. L., Fry, W. E., and Ristaino, J. B. 2012. Recent genotypes of Phytophthora infestans in eastern United States reveal clonal populations and reappearance of mefenoxam sensitivity. Plant Dis. 96:1323-1330

Isolates of Phytophthora infestans $(n=178)$ were collected in 2002 to 2009 from the eastern United States, Midwestern United States, and eastern Canada. Multilocus genotypes were defined using allozyme genotyping, and DNA fingerprinting with the RG-57 probe. Several previously described and three new mulitilocus genotypes were detected. The US- 8 genotype was found commonly on commercial potato crops but not on tomato. US-20 was found on tomato in North Carolina from 2002 through 2007 and in Florida in 2005. US-21 was found on tomato in North Carolina in 2005 and Florida in 2006 and 2007. US-22 was detected on tomato in 2007 in Tennessee and New York and became widespread in 2009. US-22 was found in 12 states on tomato and potato and was spread on tomato transplants. This genotype accounted for about $60 \%$ of all the isolates genotyped. The US-23 genotype was

found in Maryland, Virginia, Pennsylvania, and Delaware on both tomato and potato in 2009. The US-24 genotype was found only in North Dakota in 2009. A1 and A2 mating types were found in close proximity on potato and tomato crops in Pennsylvania and Virginia; therefore, the possibility of sexual reproduction should be monitored. Whereas most individuals of US-8 and US-20 were resistant to mefenoxam, US-21 appeared to be intermediately sensitive, and isolates of US-22, US-23, and US-24 were largely sensitive to mefenoxam. On the basis of sequence analysis of the ras gene, these latter three genotypes appear to have been derived from a common ancestor. Further field and laboratory studies are underway using simple sequence repeat genotyping to monitor current changes in the population structure of $P$. infestans causing late blight in North America.
\end{abstract}

Late blight of potato and tomato caused by Phytophthora infestans (Mont.) de Bary is a devastating disease worldwide and led to the Irish potato famine in $1845(5,6)$. Late blight is considered the most important biotic constraint to potato production worldwide and is a major threat to food security $(1,42)$. Under favorable weather conditions, tomato and potato crops can be destroyed within days (6). Yield losses caused by late blight and the cost of control measures have been estimated to exceed $\$ 6.7$ billion annually $(4,32,34)$. Socioeconomic hardships are still caused by the disease, as evidenced by the severe epidemics that occurred in Russia in the 1990s (17) and in the northeastern United States in 2009 (40).

P. infestans is a heterothallic oomycete plant pathogen more closely related to brown algae than to true fungi (30). The pathogen reproduces predominately by asexual sporangia formed on infected host tissue. Sporangia can be dispersed by rain splash very locally (meters) and by wind for hundreds of meters to kilometers. Movement over continental distances is typically via infected plant materials. The pathogen typically survives from season to season as mycelia in infected potato tubers, in volunteer

Corresponding author: J. B. Ristaino, E-mail: Jean_Ristaino@ncsu.edu

* The $\boldsymbol{e}$-Xtra logo stands for "electronic extra" and indicates that three supplementary tables are available online.

Accepted for publication 2 April 2012.

http://dx.doi.org/10.1094/PDIS-03-11-0156-RE

(C) 2012 The American Phytopathological Society plants, or in infected culled potato tubers that can serve as initial inoculum and contribute to epidemic development on subsequent crops. When both $\mathrm{A} 1$ and $\mathrm{A} 2$ mating type strains are present, sexual reproduction and oospore formation can occur (22). Oospores are thick-walled spores that can overwinter and act as a source of inoculum for early infections the following season (2). Populations of $P$. infestans are genotypically more diverse when sexual reproduction occurs $(15,49)$.

Potato and tomato late blight epidemics in 2009 in the eastern United States were severe. Widespread inoculum that moved on infected tomato transplants, above-normal rainfall, and cool weather conditions that occurred early and lasted well into July in most areas of the eastern United States led to extensive disease outbreaks (41). Tomato late blight occurred in the southeastern United States in winter tomato in Florida through March 2009; in late April in Beaufort, SC; and in early June in Charleston, SC (T. Keinath, personal communication). The disease was found on potato in eastern North Carolina in Tyrell, Pasquotank, and Camden Counties in late May and early June on the DELMARVA Peninsula (Deleware, Maryland, and Virginia). In late June, epidemics in the northeast became severe as tomato transplants infected with $P$. infestans were distributed through the major garden center chains from Maryland to Maine. The pathogen quickly spread from backyard garden tomato plants to commercial fields of tomato and potato. The disease did not appear on tomato in northeastern Georgia and western North Carolina until late July. Late blight appeared in Wisconsin and North Dakota in commercial production areas in mid-August and caused severe losses in some fields. The disease led to millions of dollars of lost income to growers in many areas of the northeastern United States, and some organic tomato growers abandoned production altogether. The 
pathogen has reemerged as a significant disease threat to the organic tomato industry in the United States, where management options are limited (46).

New strains of the pathogen have migrated worldwide to exacerbate disease (21). The global population structure of $P$. infestans includes a series of migrations and displacements of clonal lineages $(10,20,26,38,44)$. In contrast to parts of Europe, where pathogen populations are genetically very diverse, the genetic structure of $P$ infestans has been much simpler and largely clonal in the United States and Canada, consisting of a few multilocus genotypes (21). This is despite the occurrence of both A1 and A2 mating types in the United States. In the United States, greater genetic diversity of the pathogen has been observed on tomato than on potato, and tomato-specific lineages have been reported $(19,26,36,48)$. In the mid-1990s, the majority of the genotypes on tomato were US-6, US-7, US-11, and US-17 whereas, on potato, the US-8 genotype was the most frequent genotype in some parts of the United States (26). Subsequently, US-18 and US-19 were found on tomato (48). A recent study in Florida documented the presence of two new genotypes named US-20 and US-21 on tomato, and the continued presence of the US- 8 genotype on potato (45).

Our goal was to gain a contemporary understanding of the dominant multilocus genotypes of $P$. infestans on tomato and potato in the eastern part of the United States. We wanted to know if populations are still likely to be highly clonal and to determine whether previously dominant multilocus genotypes were still dominant. We also identified the widespread genotype present on tomato transplants and examined the evolutionary relationships of the most recent clonal lineages identified. A preliminary report of this work has been published (33).

\section{Materials and Methods}

Isolates. We collected and cultured 178 isolates of $P$. infestans from 2002 to 2009. During the period between 2002 and 2008, epidemics were sporadic in the eastern United States; therefore, fewer isolates from that time period were obtained. In 2009, as disease reports began to emerge in the eastern United States from plant disease clinics and extension faculty in our network, we collected isolates from many states. Isolates were analyzed using a series of molecular markers, and mating type and sensitivity to mefenoxam was determined.

Isolates of $P$. infestans were collected from tomato $(n=40)$ between 2002 and 2008 from Florida, Tennessee, North Carolina, and New York. However, in 2009, the widespread epidemic enabled a much wider sampling (12 states and Canada), including both potato $(n=57)$ and tomato $(n=81)$ (Tables 1 and 2; Supplementary Table S1). Sporangia were removed from the infected tissue and plated on nonamended or antibiotic-amended Rye-V8 medium (8) at $18^{\circ} \mathrm{C}$. Some tomato strains from North Carolina were maintained in planta by inoculating sporangia $\left(5.0 \times 10^{3}\right.$ sporangia/ml $)$ on excised healthy tomato cuttings that were placed in a plastic vial with distilled water in a plastic box until isolations could be done.

Mating type. Mating types were determined by pairing an A1 tester or an A2 tester isolate on clarified V8 agar with each test isolate (11). A mycelial plug (8 $\mathrm{mm}$ in diameter) of a known A1 or A2 isolate was placed on one side of a petri dish $(90 \mathrm{~mm}$ in diameter) and a mycelial plug of an unknown isolate at the other side. Oospore formation was checked after 10 to 14 days of incubation at $18^{\circ} \mathrm{C}$ in the dark, using a microscope. Isolates that produced oospores with the known A1 tester isolate were designated as the A2 mating type and isolates that produced oospores with the known A2 tester isolate were designated the A1 mating type. Positive controls consisted of pairings between the opposite mating type of tester isolates, and negative controls consisted of pairings between isolates of the same mating type.

Mefenoxam sensitivity. Sensitivity to mefenoxam was estimated on the vast majority of isolates $(n=155)$ based on radial growth on mefenoxam-amended Rye-V8 agar, as described previously (12). An 8-mm-diameter mycelial plug from a 7- to 14day-old colony was placed at the center of a petri plate containing Rye-V8 agar amended with mefenoxam (Ridomil 2E; Syngenta, Research Triangle Park, NC) at 5 or $100 \mu \mathrm{g} / \mathrm{ml}$. Control plates

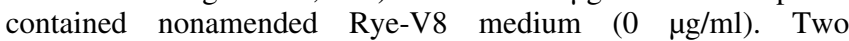
replications were conducted per treatment for each isolate, and the experiment was done at least twice. Plates were maintained at $18^{\circ} \mathrm{C}$ in the dark. Radial growth of each colony was measured after 10 to 14 days, and the relative growth of each isolate at each mefenoxam concentration was calculated as a percentage of the

Table 1. Summary of multilocus genotypes of Phytophthora infestans collected from 2002 to 2008 in North Carolina (NC), Tennessee (TN), Florida (FL). and New York (NY)

\begin{tabular}{|c|c|c|c|c|c|c|c|c|c|}
\hline \multirow[b]{2}{*}{ State, year } & \multirow[b]{2}{*}{$n^{\mathbf{b}}$} & \multirow[b]{2}{*}{ Host } & \multirow[b]{2}{*}{$\mathbf{M T}^{\mathrm{c}}$} & \multicolumn{2}{|c|}{ Allozyme genotype ${ }^{a}$} & \multirow{2}{*}{$\begin{array}{l}\text { Mefenoxam } \\
\text { sensitivity }^{d}\end{array}$} & \multirow[b]{2}{*}{ mtDNA $^{\mathrm{e}}$} & \multirow[b]{2}{*}{ Genotype $^{f}$} & \multirow[b]{2}{*}{ RG57 RFLPg } \\
\hline & & & & Gpi & Pep & & & & \\
\hline \multicolumn{10}{|l|}{$\overline{\mathrm{NC}}$} \\
\hline 2002 & 1 & Tomato & $\mathrm{A} 2$ & $100 / 100$ & $100 / 100$ & $\mathrm{R}$ & Ia & US-20 & $1,3,5,7,10,13,14,16,18,20,21,24,25$ \\
\hline 2003 & 1 & Tomato & A2 & $100 / 100$ & $100 / 100$ & $\mathrm{R}$ & Ia & US-20 & $1,3,5,7,10,13,14,16,18,20,21,24,25$ \\
\hline 2004 & 5 & Tomato & $\mathrm{A} 2$ & $100 / 100$ & $100 / 100$ & $\mathrm{R} / \mathrm{I}$ & Ia & US-20 & $1,3,5,7,10,13,14,16,18,20,21,24,25$ \\
\hline 2005 & 3 & Tomato & $\mathrm{A} 2$ & $100 / 100$ & $100 / 100$ & $\mathrm{R} / \mathrm{I}$ & Ia & US-20 & $1,3,5,7,10,13,14,16,18,20,21,24,25$ \\
\hline 2006 & 1 & Tomato & A2 & $100 / 100$ & $100 / 100$ & I & Ia & US-20 & $1,3,5,7,10,13,14,16,18,20,21,24,25$ \\
\hline 2007 & 1 & Tomato & A2 & $100 / 100$ & $100 / 100$ & I & Ia & US-20 & $1,3,5,7,10,13,14,16,18,20,21,24,25$ \\
\hline 2007 & 1 & Tomato & A2 & $100 / 122$ & $100 / 100$ & I & Ia & US-21 & $1,5,10,13,14,18,20,21,24,25$ \\
\hline \multicolumn{10}{|l|}{ FL } \\
\hline 2005 & 2 & Tomato & A2 & $100 / 100$ & $100 / 100$ & $\mathrm{~S} / \mathrm{I}$ & Ia & US-20 & $1,3,5,7,10,13,14,16,18,20,21,24,25$ \\
\hline 2006 & 3 & Tomato & $\mathrm{A} 2$ & $100 / 122$ & $100 / 100$ & I & Ia & US-21 & $1,5,10,13,14,18,20,21,24,25$ \\
\hline 2007 & 2 & Tomato & A2 & $100 / 122$ & $100 / 100$ & $\mathrm{~S} / \mathrm{I}$ & Ia & US-21 & $1,5,10,13,14,18,20,21,24,25$ \\
\hline 2008 & 15 & Tomato & A2 & $100 / 122$ & $100 / 100$ & I & Ia & US-22 & $1,5,13,14,16,20,21,24,25$ \\
\hline \multicolumn{10}{|r|}{ 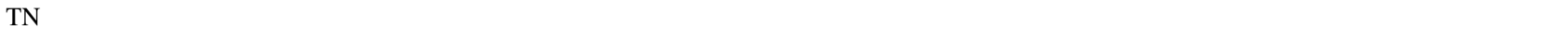 } \\
\hline 2007 & 3 & Tomato & $\mathrm{A} 2$ & $100 / 122$ & $100 / 100$ & I & Ia & US-22 & $1,5,13,14,16,20,21,24,25$ \\
\hline \multicolumn{10}{|r|}{ 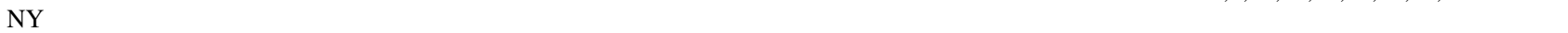 } \\
\hline 2007 & 1 & Tomato & A2 & $100 / 122$ & $100 / 100$ & I & Ia & US-22 & $1,5,13,14,16,20,21,24,25$ \\
\hline 2008 & 1 & Tomato & $\mathrm{A} 2$ & $100 / 122$ & $100 / 100$ & I & Ia & US-22 & $1,5,13,14,16,20,21,24,25$ \\
\hline
\end{tabular}

${ }^{a}$ Allozyme genotyping done using methods of Goodwin et al. (25); Gpi = glucose-6-phosphate isomerase and Pep = peptidase.

${ }^{\mathrm{b}}$ Number of isolates.

c Mating type.

${ }^{\mathrm{d}}$ Sensitivity to mefenoxam. $\mathrm{R}=$ mefenoxam resistant, $\mathrm{I}=$ intermediate, and $\mathrm{S}=$ sensitive by the methods of Deahl et al. (11).

${ }^{\mathrm{e}}$ mtDNA haplotype determined by the methods of Griffith and Shaw (28).

${ }^{\mathrm{f}}$ US-22 genotype isolates collected by Meg McGrath in Long Island, NY in September 2007 and October 2008, Ken Deahl in TN in July 2007, and Pam Roberts in FL in 2008.

g DNA fingerprinting by restriction fragment length polymorphism (RFLP) by methods of Goodwin et al. (24) and genotype name assigned. 
growth on nonamended Rye-V8 medium (control plate). Isolates with a colony diameter less than $40 \%$ of the nonamended control at 5 and $100 \mu \mathrm{g} / \mathrm{ml}$ were classified as mefenoxam sensitive. Isolates with a colony diameter greater than $40 \%$ of the nonamended control at $5 \mu \mathrm{g} / \mathrm{ml}$ but less than $40 \%$ of the nonamended control at $100 \mu \mathrm{g} / \mathrm{ml}$ were classified as intermediate. Isolates with a colony diameter greater that $40 \%$ of the nonamended control at both 5 and $100 \mu \mathrm{g} / \mathrm{ml}$ were classified as mefenoxam insensitive (resistant) (12).

Allozyme analysis. Allozyme genotypes were determined for the vast majority of isolates $(n=177)$ at glucose-6-phosphate isomerase (Gpi) and peptidase (Pep) loci. Mycelia obtained from pea broth culture or directly from sporangia were placed in sterile 1.5$\mathrm{ml}$ microcentrifuge tubes and extracted according to Goodwin et al. (25). Allozyme genotypes were determined at the Gpi and Pep loci by cellulose-acetate electrophoresis. Isolates of two clonal genotypes-US-1 (Gpi 86/100, Pep 92/100) and US-8 (Gpi 100/111/122, Pep 100/100)—were used as standards on each acetate plate. Migration distances of proteins from the unknown isolates were compared with migration distances of proteins from the tester genotypes. Alleles in individual isolates were scored based on the migration of their proteins relative to the protein produced at the 100 allele, which is the most common allele.

DNA extraction. Mycelia of a subset of isolates from pea broth culture were harvested by centrifugation at $13,000 \mathrm{rpm}$, rinsed in sterile distilled water, dried, and either stored at $-20^{\circ} \mathrm{C}$ or used immediately for DNA extraction. Total DNA was extracted from the mycelia by using a cetyltrimethylammonium bromide (SigmaAldrich, St. Louis) protocol (48). DNA was diluted 1:10 or 1:100 and stored at $-20^{\circ} \mathrm{C}$ until use.

mtDNA haplotype analysis. The vast majority of isolates $(n=$ 128) were analyzed for mtDNA haplotype. DNA extraction, polymerase chain reactions (PCRs), and digestion with restriction enzymes were used to determine haplotypes according to the methods of Griffith and Shaw (28) modified by Wangsomboondee et al. (48). Four different mitochondrial haplotypes have been described in P. infestans: Ia, Ib, IIa, and IIb (7). The mitochondrial haplotypes of isolates were determined by comparing their patterns to reference isolates of mtDNA haplotypes Ia, Ib, IIa, and IIb.

Restriction fragment length polymorphism genotype. Isolates were grown in pea broth for 14 days at $18^{\circ} \mathrm{C}$. The mycelia were vacuum-filtered through Whatman Number 1 filters lyophilized at $-5^{\circ} \mathrm{C}$ overnight. Total DNA was extracted using Sigma's GenElute Plant Genomic DNA Extraction Kit and restriction fragment length polymorphism (RFLP) analysis was done using the RG-57 probe carried out using the methodology described by Goodwin et al. (24) on 132 isolates. Transfer to a positively charged nylon membrane, hybridization with a nonradioactive RG-57 probe, and autoradiography were all performed according to the manufacturer's instructions (Roche Applied Science DIG High Prime Labeling and Detection Kit II). The RFLP genotype of the isolates was determined by comparing their patterns with those of reference isolates US-1, US-8, and US-18 (18). Data obtained from RFLP analysis were used to name the clonal lineages after comparison with previously reported U.S. lineages $(18,26,48)$.

Simple sequence repeat analysis. Simple sequence repeats (SSRs) were analyzed on a subset of isolates $(n=56)$ from New York, Maine, Florida, and Virginia using slightly modified published protocols (37). We analyzed SSRs on the previously identified US-8 and US-22 clonal lineages determined previously by RFLP analysis, because these lineages varied in mefenoxam sensitivity. Many of the U.S. clonal lineages have subsequently been tested with the complete set of SSR markers and will be published elsewhere (W. Fry, unpublished data). The SSR loci that were amplified included Pi4B, PiG11 (35), Pi02, Pi89, Pi04, Pi70, Pi56, Pi 63, D13, Pi16, Pi33, and Pi66 (37). PCR products were mixed

Table 2. Summary by state of multilocus genotypes of Phytophthora infestans collected during 2009 late blight epidemics

\begin{tabular}{|c|c|c|c|c|c|c|c|c|c|}
\hline \multirow[b]{2}{*}{ State } & \multirow[b]{2}{*}{$n^{\mathbf{b}}$} & \multirow[b]{2}{*}{ Host } & \multirow[b]{2}{*}{$\mathbf{M T}^{\mathbf{c}}$} & \multicolumn{2}{|c|}{ Allozyme genotype ${ }^{a}$} & \multirow{2}{*}{$\begin{array}{l}\text { Mefenoxam } \\
\text { sensitivity }^{d}\end{array}$} & \multirow[b]{2}{*}{ mtDNA $^{\mathrm{e}}$} & \multirow[b]{2}{*}{ Genotype } & \multirow[b]{2}{*}{ RG57 RFLP ${ }^{f}$} \\
\hline & & & & $G p i$ & Pep & & & & \\
\hline Florida & 8 & Tomato & A2 & $100 / 122$ & $100 / 100$ & $\mathrm{~S}$ & Ia & US-22 & $1,5,13,14,16,20,21,24,25$ \\
\hline \multirow[t]{2}{*}{ North Carolina } & 4 & Potato & A2 & $100 / 111 / 122$ & $100 / 100$ & $\mathrm{R} / \mathrm{I}$ & Ia & US-8 & $1,5,10,13,14,16,20,21,23,24,25$ \\
\hline & 4 & Tomato & A2 & $100 / 122$ & $100 / 100$ & $\mathrm{~S}$ & Ia & US-22 & $1,5,13,14,16,20,21,24,25$ \\
\hline Tennessee & 1 & Tomato & A2 & $100 / 122$ & $100 / 100$ & $\mathrm{~S}$ & Ia & US-22 & $1,5,13,14,16,20,21,24,25$ \\
\hline \multirow[t]{2}{*}{ Maryland } & 1 & Potato & A1 & $100 / 100$ & $100 / 100$ & $\mathrm{~S} / \mathrm{I}$ & Ia & US-23 & $1,2,5,6,10,13,14,17,20,21,24,24 a, 25$ \\
\hline & 2 & Tomato & A2 & $100 / 122$ & $100 / 100$ & $\mathrm{~S}$ & Ia & US-22 & $1,5,13,14,16,20,21,24,25$ \\
\hline \multirow[t]{4}{*}{ Virginia } & 1 & Potato & A2 & $100 / 111 / 122$ & $100 / 100$ & $\mathrm{R} / \mathrm{I}$ & Ia & US-8 & $1,5,10,13,14,16,20,21,23,24,25$ \\
\hline & 3 & Tomato & A1 & $100 / 100$ & $100 / 100$ & $\mathrm{~S}$ & Ia & US-23 & $1,2,5,6,10,13,14,17,20,21,24,24 a, 25$ \\
\hline & 2 & Tomato & A2 & $100 / 122$ & $100 / 100$ & $\mathrm{~S}$ & Ia & US-22 & $1,5,13,14,16,20,21,24,25$ \\
\hline & 2 & Potato & A2 & $100 / 122$ & $100 / 100$ & $\mathrm{~S}$ & Ia & US-22 & $1,5,13,14,16,20,21,24,25$ \\
\hline West Virginia & 3 & Tomato & A2 & $100 / 122$ & $100 / 100$ & $\mathrm{~S}$ & Ia & US-22 & $1,5,13,14,16,20,21,24,25$ \\
\hline Delaware & 4 & Potato & A1 & $100 / 100$ & $100 / 100$ & $\mathrm{~S} / \mathrm{I}$ & Ia & US-23 & $1,2,5,6,10,13,14,17,20,21,24,24 a, 25$ \\
\hline New Jersey & 1 & Tomato & A2 & $100 / 122$ & $100 / 100$ & $\mathrm{~S} / \mathrm{I}$ & Ia & US-22 & $1,5,13,14,16,20,21,24,25$ \\
\hline \multirow[t]{5}{*}{ Pennsylvania } & 5 & Potato & A1 & $100 / 100$ & $100 / 100$ & $\mathrm{~S} / \mathrm{I}$ & Ia & US-23 & $1,2,5,6,10,13,14,17,20,21,24,24 \mathrm{a}, 25$ \\
\hline & 2 & Potato & A2 & $100 / 122$ & $100 / 100$ & $\mathrm{~S} / \mathrm{I}$ & Ia & US-22 & $1,5,13,14,16,20,21,24,25$ \\
\hline & 7 & Potato & A2 & $100 / 111 / 122$ & $100 / 100$ & $\mathrm{R} / \mathrm{I}$ & Ia & US-8 & $1,5,10,13,14,16,20,21,23,24,25$ \\
\hline & 9 & Tomato & A1 & $100 / 100$ & $100 / 100$ & $\mathrm{~S} / \mathrm{I}$ & Ia & US-23 & $1,2,5,6,10,13,14,17,20,21,24,24 \mathrm{a}, 25$ \\
\hline & 10 & Tomato & A2 & $100 / 122$ & $100 / 100$ & $\mathrm{~S} / \mathrm{I}$ & Ia & US-22 & $1,5,13,14,16,20,21,24,25$ \\
\hline \multirow[t]{3}{*}{ New York } & 33 & Tomato & A2 & $100 / 122$ & $100 / 100$ & I & Ia & US-22 & $1,5,13,14,16,20,21,24,25$ \\
\hline & 8 & Potato & A2 & $100 / 122$ & $100 / 100$ & I & Ia & US-22 & $1,5,13,14,16,20,21,24,25$ \\
\hline & 11 & Potato & A2 & $100 / 111 / 122$ & $100 / 100$ & $\mathrm{R} / \mathrm{I}$ & Ia & US-8 & $1,5,10,13,14,16,20,21,23,24,25$ \\
\hline \multirow[t]{3}{*}{ Maine } & 2 & Potato & A2 & $100 / 122$ & $100 / 100$ & $\mathrm{~S}$ & Ia & US-22 & $1,5,13,14,16,20,21,24,25$ \\
\hline & 1 & Potato & A2 & $100 / 111 / 122$ & $100 / 100$ & $\mathrm{R}$ & $\mathrm{Ia}$ & US-8 & $1,5,10,13,14,16,20,21,23,24,25$ \\
\hline & 1 & Tomato & A2 & $100 / 122$ & $100 / 100$ & $\mathrm{~S}$ & Ia & US-22 & $1,5,13,14,16,20,21,24,25$ \\
\hline Indiana & 1 & Tomato & A2 & $100 / 122$ & $100 / 100$ & $\mathrm{~S}$ & Ia & US-22 & $1,5,13,14,16,20,21,24,25$ \\
\hline Wisconsin & 1 & Tomato & A2 & $100 / 122$ & $100 / 100$ & $\mathrm{~S}$ & $\mathrm{Ia}$ & US-22 & $1,5,13,14,16,20,21,24,25$ \\
\hline \multirow[t]{2}{*}{ North Dakota } & 6 & Potato & A1 & $100 / 100 / 111$ & $100 / 100$ & I & Ia & US-24 & $1,3,5,7,10,13,14,16,20,21,23,24,25$ \\
\hline & 2 & Tomato & A1 & $100 / 100 / 111$ & $100 / 100$ & $\mathrm{~S} / \mathrm{I}$ & Ia & US-24 & $1,3,5,7,10,13,14,16,20,21,23,24,25$ \\
\hline Canada & 3 & Potato & A2 & $100 / 122$ & $100 / 100$ & $\mathrm{~S}$ & Ia & US-22 & $1,5,13,14,16,20,21,24,25$ \\
\hline
\end{tabular}

a Allozyme genotyping done using methods of Goodwin et al. (25); Gpi = glucose-6-phosphate isomerase and Pep = peptidase.

b Number of isolates.

c Mating type.

${ }^{\mathrm{d}}$ Sensitivity to mefenoxam. $\mathrm{R}=$ mefenoxam resistant, $\mathrm{I}=$ intermediate, $\mathrm{S}=$ sensitive by the methods of Deahl et al. (11).

e mtDNA haplotype determined by the methods of Griffith and Shaw (28).

${ }^{\mathrm{f}}$ DNA fingerprinting by restriction fragment length polymorphism (RFLP) by methods of Goodwin et al. (24) and genotype name assigned. 
with LIZ 500 size standard (Applied Biosystems Inc., Foster City, CA), and analyzed on an ABI 373048 capillary system. Electropherograms were visualized and scored using Peak Scanner software (Applied Biosystems Inc.).

DNA amplification and sequencing. Two regions of the ras gene, a single-copy nuclear gene (9), including intron 1 (224 bp), and a 542-bp region, including exons 3-6 and introns 3-5, were amplified from a subset of isolates by PCR and sequenced. PCR reactions were done as previously described (23). Sequencing reactions were prepared using the ABI PRISM BigDye Terminator Cycle Sequencing Ready Reaction Kit and analyzed on an ABI PRISM 377 automated sequencer (Applied Biosystems Inc.). Sequences of representative haplotypes were submitted to GenBank (accession numbers JF431434 to JF431457; Supplementary Table S2).

Data statistical analysis. Statistical analyses of the nucleotide sequences were performed in SNAP Workbench version 2.0 (43). Multiple DNA sequences were aligned and edited manually with BioEdit (31). Sequence data from nuclear (IntronRas + Ras) loci were combined separately into alignment files using SNAP Combine (3). Sequences were collapsed into unique haplotypes using SNAP Map (3) after removing insertions and deletions from each of the aligned multilocus data sets and excluding infinite-sites violations. Base substitutions were categorized as phylogenetically informative or uninformative, transitions or transversions, and nonsynonymous (replacement) or synonymous amino acid changes in the coding region of each alignment. Resultant haplotype data sets were used to examine the overall support or conflict among the variable sites in the DNA sequence alignment. A site compatibility matrix was generated from each haplotype data set using SNAP Clade and Matrix (3). Compatibility matrices were used to examine compatibility or incompatibility among all variable sites, with any resultant incompatible sites removed from the data set. Data sets were also evaluated using RecMin (3) for evidence of recombination boundaries and for estimating the minimum number of recombination events. Conflicting data partitions or putative recombinant haplotypes were also excluded from further analyses. Nonrecombining data sets were collapsed into unique haplotypes excluding infinite-sites violations using SNAP Map. The nonrecombining data set included both the nuclear gene region intron 1 of ras and introns and exons 3 to 5 of ras (IntronRas + Ras).
Genealogical analysis. The ancestral history of the populations for the nonrecombining data set (nuclear IntronRas + Ras combined) were inferred using Genetree (version 9.0) and Treepic (43) in SNAP Workbench. The genealogy with the highest root probability, ages of mutations, the TMRCA of the sample, and the geographic distribution of the mutations were estimated from coalescent simulations. Coalescent analyses with population subdivision were performed and a backward migration matrix was estimated for each locus using IM. Recombinant haplotypes were identified a priori using SNAP Clade and excluded from the analysis. Coalescent simulations were performed assuming an infinite-sites model, constant population size, and population subdivision. Gene genealogies for each locus were inferred using five million simulations of the coalescent. Additionally, we performed five independent runs of five million simulations using a different starting random number seed for each run to ensure convergence.

\section{Results}

Forty isolates of $P$. infestans were collected from tomato in Florida, North Carolina, Tennessee, and New York from 2002 to 2008 These included the multilocus genotypes US-20 and US-21 (45) (Table 1). These two genotypes are both A2 mating type and Ia mtDNA haplotype. US-20 (Gpi 100/100; Pep 100/100; RG-57 $1,3,5,7,10,13,14,16,18,20,21,24,25)$ was collected on tomato each year in North Carolina from 2002 through 2007 and in Florida in 2005. US-21 (Gpi 100/122; Pep 100/100; RG-57 1,5,10,13,14, $18,20,21,24,25)$ was found on tomato in Florida in 2006 and 2007 and in North Carolina in 2007 (Table 1). The US-21 genotype appears to be a tomato-specific lineage and did not infect tomato grown adjacent to potato in the same field at the Mountain Horticultural Research Center in Fletcher, NC in 2007 (Fig. 1). US20 and US-21 share a common ras haplotype (H3) and contain three unique mutations not found among the other lineages (Fig. 2).

A new genotype proposed here for the first time as US-22 ( $G p i$ 100/122; Pep 100/100; RG-57 1,5,13,14,16,20,21,24,25) was first found in garden tomato in Tennessee and later in a commercial tomato field in Suffolk County on Long Island, NY in September 2007 and again in New York in 2008 (Table 1). The US-22 was also identified in 15 isolates from winter tomato from three counties in Florida (Collier, Manatee, and Hendry) in 2008 (Table 1). Isolates of the US-22 genotype are A2 mating type and Ia mtDNA haplotype (Table 1). The three US-22 isolates found in

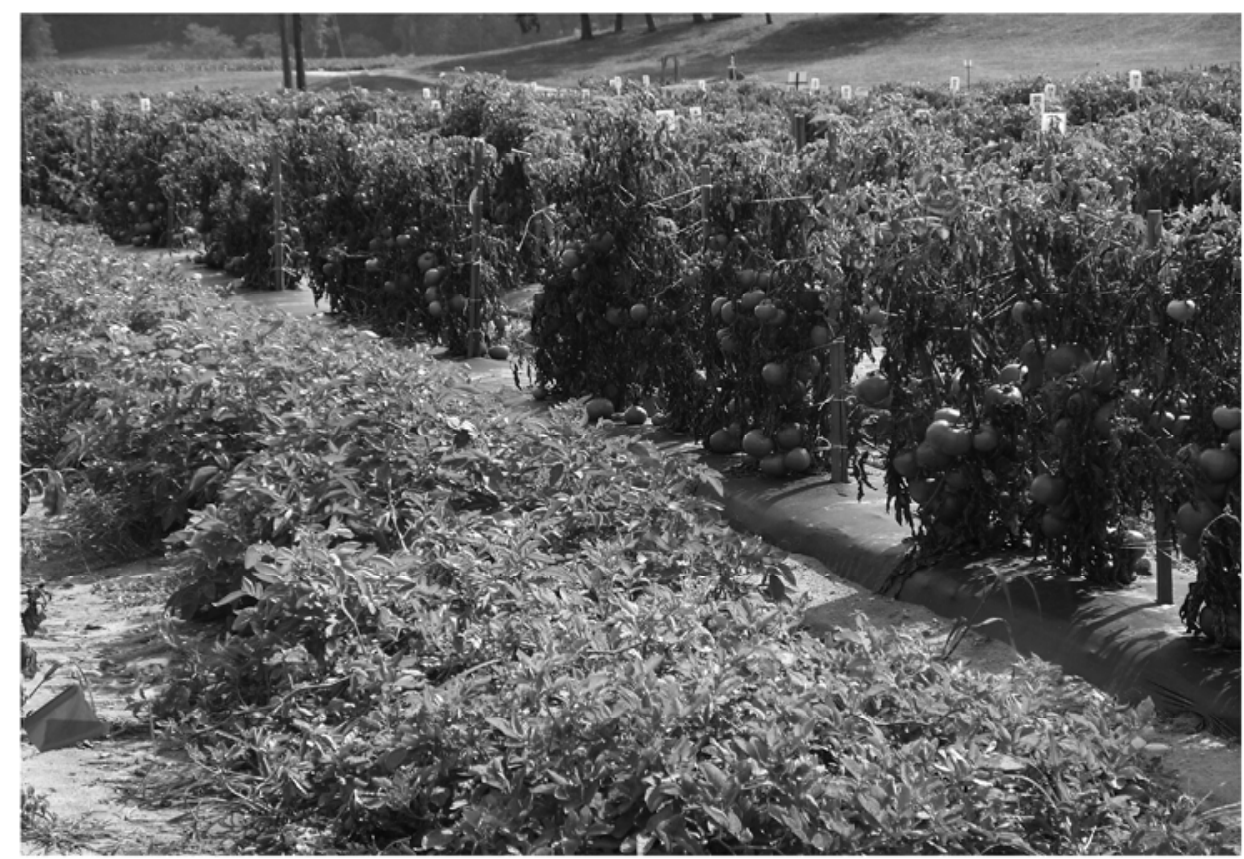

Fig. 1. Tomato late blight caused by the US-21 genotype, a tomato specific lineage of Phytophthora infestans on tomato in western North Carolina. Healthy potato in the foreground are not infected with this genotype. Photo by Kelly Ivors. 
Tennessee in 2007 share a common ras haplotype (H4) and also share a mutation (site 11) that was found in all the subsequent US22 genotypes found later in 2009 (Fig. 2).

In 2009, the US-22 genotype (Table 2) was identified in tomato transplants in home garden centers and the genotype was widespread in fields in the northeast. This genotype accounted for $61 \%$ of the isolates genotyped in 2009 and was found on both tomato and potato (Table 2). These isolates all shared a common ras haplotype (H2) and this haplotype contained five unique mutations (Fig. 2).

In addition to US-22, three other multilocus genotypes were identified among the isolates obtained from different fields in 14 states in the United States and eastern Canada in 2009 (Tables 2 and 3). The US-8 genotype was found on potato in North Carolina, Virginia, Pennsylvania, New York, and Maine, and retained its relative resistance to mefenoxam. Two new multilocus genotypes, US-23 (Gpi 100/100; Pep 100/100; RG-57 1,2,5,6,10,13,14,17, 20,21,24,24a,25) and US-24 (Gpi 100/100/111; Pep 100/100; RG$571,3,5,7,10,13,14,16,20,21,23,24,25)$ were obtained for the first time from both tomato and potato and, unlike the other genotypes, were A1 mating types (Table 3). US-8, US-23, and US-24 also shared a common ras haplotype (H2) with the 2009 US-22 isolates (Fig. 2).

In many cases, the same multilocus genotype was detected over a broad area, consistent with epidemic populations that were clonal. For example, all samples from North Carolina from 2002 to 2007 were US-20. In 2009, US-22 was detected over very broad areas in the northeastern United States. In 2009 in New York and Maine, two A2 genotypes (US-8 and US-22) were found on potato; however, US-8 was found on conventional commercial potato, whereas US-22 was found on home garden potato, indicating that these epidemic populations were clonal and that different sources of inoculum were responsible for disease. In North Dakota in 2009, all samples were US-24 and potato seed was suspected as a source of inoculum.

SSR analysis was conducted on a subset of the US-8 and US-22 isolates collected in New York, Maine, Florida, and Tennessee. The SSR alleles for the US-8 and US-22 genotypes were identified and all the SSR alleles at each individual locus were identical for all isolates of either the US-22 or US-8 genotypes tested (Table 3), also indicating that both lineages were highly clonal. The US-8 and US-22 genotypes could be distinguished from each other at the SSR loci Pi4B, PiG11, Pi70, Pi16, and Pi33 (Table 3).

There were several instances in 2009 when more than one mating type was detected in a given state and, in some cases, more than one mating type was found in a county in the same state. The proximity of A1 and A2 mating types is of particular interest because of the possibility of sexual reproduction. Both the A1 and A2 mating types were found on potato (different fields) in the same county in two cases in Pennsylvania (Blair and Centre Counties). In Accomak County, VA, US-23 (A1) was found on tomato and US-8 (A2) was detected on potato. However, because populations were highly clonal, the likelihood of sexual reproduction is low.

Most US-22 isolates were sensitive to mefenoxam but a few were intermediate in sensitivity. Isolates of the US-23 genotype found along the DELMARVA Peninsula in Virginia, Maryland, and Delaware and in Pennsylvania were also sensitive to mefenoxam. The US-24 genotype was found only in North Dakota in commercial potato and tomato fields (Tables 2 and 3), and most isolates were intermediate in their resistance to mefenoxam.

Sequence diversity and evolutionary relationships among haplotypes. Sequence diversity in intron 1 of the ras gene was higher than in exons 3 to 6 of the ras gene. Two synonymous substitution sites were found in exon 5 of the ras gene. Nucleotide diversity $(\pi)$, the average number of nucleotide differences per site between two sequences, for the pooled sample (tomato and potato) was $5.70 \times 10^{-3}$ (Table 4). The Watterson's estimate $\left(\theta_{\mathrm{W}}\right)$ of population mean mutation rate for the pooled sample was 2.033 . Isolates from potato and tomato had similar nucleotide diversity estimates but isolates found on tomato had higher mean mutation rates $\left(\theta_{\mathrm{W}}=2.189\right)$ compared with those from potato $\left(\theta_{\mathrm{W}}=1.881\right)$ (Table 4).

In total, 766 nucleotides of nuclear ras gene (intron 1 and exon 3 to 6 regions) were sequenced for a subset of isolates (Tables 4). Allele sequences were used for the analysis due to the heterozygous sites in the ras gene (Supplementary Table S3). There are two allele sequences for each isolate and the phases were determined and coded. In the case of homozygous sequence, two identical sequences were used for the analysis. Eleven segregating nucleotide sites were identified for the ras gene. Five segregating nucleotide sites were identified in intron 1 and six segregating nucleotide sites were identified in exons 3 to 6 of the ras gene that were phylogenetically informative (4). Four different haplotypes were identified. Haplotype 1 (H1) was the most common and distributed among many of the isolates sequenced (Fig 2). Haplotype 2 (H2) was identified among the US-8, US-22, US-23, and US-24 genotypes. Haplotype 3 (H3) was identified among the US-20 or US-21 genotypes, while haplotype 4 (H4) was found only among isolates collected in Tennessee in 2007 (US-22).

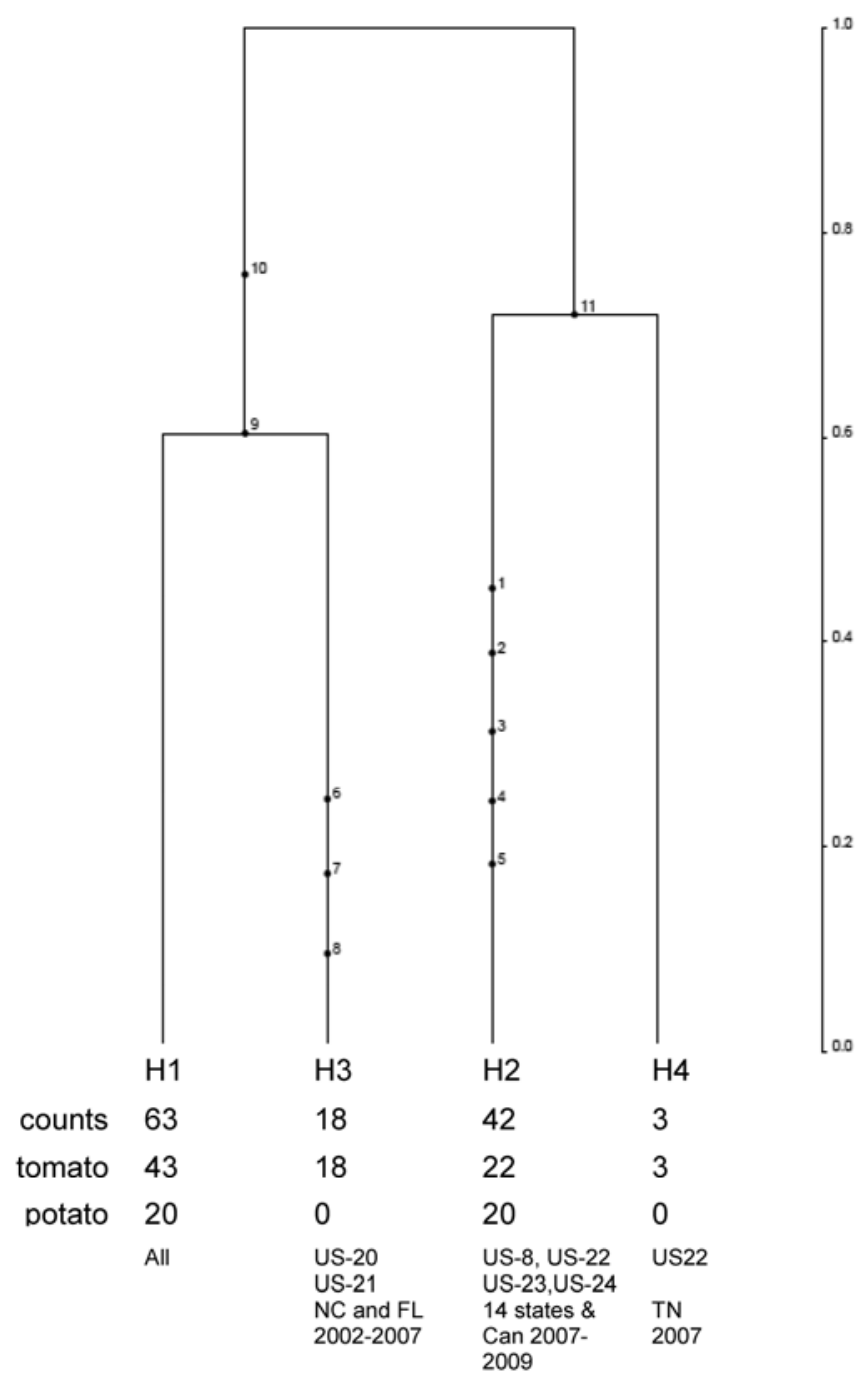

Fig. 2. Rooted coalescent-based gene genealogy showing the distribution of mutations for the nuclear ras locus (IntronRas + Ras) for populations of Phytophthora infestans from tomato and potato collected from 2002 to 2009 in the eastern United States generated using GENETREE (43). Time scale is in coalescent units of effective population size. The direction of divergence is from the top (past-oldest) to the bottom (present-youngest). The numbers below the tree from top to bottom designate each distinct haplotype and its count (i.e., the number of occurrences of the haplotype in the sample) and the count of each haplotype in each population. Relationship to U.S. restriction fragment length polymorphism genotypes is also shown. $\mathrm{NC}=$ North Carolina, FL = Florida, Can = Canada, and $\mathrm{TN}=$ Tennessee. 


\section{Discussion}

Five multilocus genotypes of $P$. infestans are described in our study from populations of the pathogen sampled in the eastern and midwestern United States between 2002 and 2009 (Table 3). One of these genotypes, US-22, was very broadly distributed in 2009 and detected in 12 states and eastern Canada. This genotype was found on tomato transplants prior to sale in several states (Maine and New York). These plants were bought by homeowners and planted in home gardens in late June and early July 2009. Weather very favorable for late blight in the summer of 2009 enabled this genotype to cause considerable damage to tomato throughout the northeastern United States in 2009.

The widespread occurrence of a single multilocus genotype starting first on tomato is unusual. In our experience, infected tomato transplants have not been a source of major late blight outbreaks in eastern United States previously. In contrast, infected potato tubers (seed tubers, cull tubers, and volunteers) are the more usual source of this pathogen. However, the synchronous appearance of the infected transplants in garden centers in mid- to late June and the cool wet weather at that time favored a pandemic. These transplants were initially started from seed in a production facility in the south. Very small plants ("plugs") were then sent to growers in the north for further growing and "hardening off".

Infected transplants were not the only source of inoculum for late blight outbreaks in 2009. The US-8 genotype most likely survived in potato tubers to initiate disease found in North Carolina, Virginia, Pennsylvania, and New York. In addition, a new genotype, US-23 was found on tomato and potato in Virginia, Maryland, and Delaware, respectively, in late May and later on both hosts in Pennsylvania (Table 2). The source of this genotype remains unknown. Finally, US-24 was found in North Dakota on potato initially but the genotype was subsequently found also on tomato in that state. Although the original source of these genotypes is unknown, the ras analysis indicates that US-22, US-23, and US-24 are all related.

The concern about sexual reproduction remains. The fact that both US-22 (A2) and US-23 (A1) multilocus genotypes were found in the same host and in two counties in Pennsylvania (Blair and Centre) is worrisome. In Virginia, the occurrence of US-23 (A1) in tomato fields in close proximity to potato fields with the A2 mating type is cause for concern. This is because physical association of two mating types creates the possibility of sexual reproduction. The resulting oospores enable overwintering of this organism in the absence of a host and also the generation of recombinant genotypes. This type of close proximity of opposite mating types of $P$. infestans is not unprecedented and occurred in the 1990s in New York and elsewhere, when the US-1 and US-7 or US-8 and US-17 multilocus genotypes were widely distributed in the United States $(11,27,39)$.

The possibility of sexual reproduction in the pathogen should continue to be examined by further sampling and genotyping in these areas of the eastern United States. In the Netherlands, Poland, and Nordic countries, sexual reproduction has become common and led to increased genetic diversity in the pathogen, and also earlier epidemic onset from survival of soilborne oospores $(2,14-16,47)$. Even though both mating types of the pathogen have been found commonly in the United States and Canada in the past, it appears that populations of $P$. infestans remain largely clonal and there is currently no well-documented example of sexual reproduction of the pathogen in United States $(21,27)$.

During the past two decades in the United States, populations of the pathogen on tomato have been genotypically more diverse than those on potato $(19,21,26,48)$. During 1993 and 1994, the US-7 genotype $(76 \%)$ was dominant. Subsequently, US-11 and US-17 became dominant (26). Between 1995 and 1998, the US-18 and

Table 3. Summary of multilocus genotypes of Phytophthora infestans collected in the United States and Canada, 2002 to 2009

\begin{tabular}{|c|c|c|c|c|c|c|c|}
\hline \multirow[b]{2}{*}{ Genotype $^{b}$} & \multirow[b]{2}{*}{ Host } & \multirow[b]{2}{*}{$\mathbf{M T}^{\mathrm{c}}$} & \multicolumn{2}{|c|}{ Allozyme genotype ${ }^{a}$} & \multirow{2}{*}{$\begin{array}{l}\text { Mefenoxam } \\
\text { sensitivity }\end{array}$} & \multirow[b]{2}{*}{ mtDNA $^{\mathrm{e}}$} & \multirow[b]{2}{*}{ RG57 RFLP } \\
\hline & & & Gpi & Pep & & & \\
\hline US- $8^{g}$ & Potato & A2 & $100 / 111 / 122$ & $100 / 100$ & $\mathrm{R} / \mathrm{I}$ & Ia & $1,5,10,13,14,16,20,21,23,24,25$ \\
\hline US-20 & Tomato & A2 & $100 / 100$ & $100 / 100$ & $\mathrm{R} / \mathrm{I}$ & Ia & $1,3,5,7,10,13,14,16,18,20,21,24,25$ \\
\hline US-21 & Tomato & A2 & $100 / 122$ & $100 / 100$ & $\mathrm{R} / \mathrm{I} / \mathrm{S}$ & Ia & $1,5,10,13,14,18,20,21,24,25$ \\
\hline $\mathrm{US}-22^{\mathrm{h}}$ & Potato and tomato & A2 & $100 / 122$ & $100 / 100$ & $\mathrm{~S} / \mathrm{I}$ & Ia & $1,5,13,14,16,20,21,24,25$ \\
\hline US-23 & Potato and tomato & A1 & $100 / 100$ & $100 / 100$ & $\mathrm{~S} / \mathrm{I}$ & Ia & $1,2,5,6,10,13,14,17,20,21,24,24 a, 25$ \\
\hline US-24 & Potato & A1 & $100 / 100 / 111$ & $100 / 100$ & I & Ia & $1,3,5,7,10,13,14,16,20,21,23,24,25$ \\
\hline
\end{tabular}

a Allozyme genotyping done using methods of Goodwin et al. (25); Gpi= glucose-6-phosphate isomerase and Pep = peptidase.

${ }^{\mathrm{b}}$ US-8 was found on only on potato in North Carolina, Virginia, Pennsylvania, New York, and Maine; US-20 was found in western North Carolina tomato between 2002 and 2007; US-21 was found in Florida in 2006 to 2007 and North Carolina in 2007; US-22 was first found in Tennessee in 2007, in Long Island NY in September 2007 and October 2008, and in Florida in winter tomato in 2008, and it is the genotype that was widespread in 2009 on tomato transplants in the northeast United States; US-23 was found in 2009 and, along with US-22, caused the majority of potato and tomato late blight outbreaks in the eastern United States; and US-24 was found only in North Dakota on potato in 2009.

${ }^{c}$ Mating type.

${ }^{\mathrm{d}}$ Sensitivity to mefenoxam. $\mathrm{R}=$ mefenoxam resistant, $\mathrm{I}=$ intermediate, $\mathrm{S}=$ sensitive.

e mtDNA haplotype determined by the methods of Griffith and Shaw (28).

${ }^{\mathrm{f}}$ DNA fingerprinting by restriction fragment length polymorphism (RFLP) by methods of Goodwin et al. (24).

$\mathrm{g}$ The simple sequence repeat (SSR) alleles for the US-8 genotype are 163/165, 176/179, 213/226, 155/155, 166/170, 190/190, 257/257, 280/280, 106/110,173/177, and 202/202 for the Pi02, Pi89, Pi4B, PiG11, Pi04, Pi70, Pi56, Pi63, D13, Pi16, and Pi33 loci, respectively, by the methods of Lee et al. (37).

h SSR alleles for the US-22 genotype were 163/165, 176/179, 213/213, 131/155, 166/170, 190/193, 257/257,280/280, 177/177, and 202/205 for the Pi02, Pi89, Pi4B, PiG11, Pi04, Pi70, Pi56, Pi63, Pi16, and Pi33 loci, respectively, by the methods of Lee et al. (37).

Table 4. Population statistics and diversity estimates based on variation in nuclear ras loci (IntronRas + Ras) of Phytophthora infestans ${ }^{\mathrm{a}}$

\begin{tabular}{|c|c|c|c|c|c|c|c|}
\hline \multirow[b]{2}{*}{ Locus, population } & \multicolumn{5}{|c|}{ Sample summaries } & \multicolumn{2}{|c|}{ Parameter estimates } \\
\hline & $l$ & $n$ & $s$ & $h$ & $k$ & $\pi(\mathrm{SE})\left(\times 10^{-3}\right)$ & $\theta_{\mathrm{W}}$ \\
\hline Potato & 766 & 40 & 8 & 2 & 4.103 & $5.36(0.19)$ & 1.881 \\
\hline Tomato & 766 & 86 & 11 & 4 & 4.182 & $5.46(0.44)$ & 2.189 \\
\hline Pooled & 766 & 126 & 11 & 4 & 4.369 & $5.70(0.28)$ & 2.033 \\
\hline
\end{tabular}

${ }^{a} l$, consensus sequence length; $n$, sample size (number of alleles for nuclear locus); $s$, segregating nucleotide sites; $h$, haplotypes; $k$, average number of pair wise nucleotide differences; $\pi$, average number of base differences per site; SE, standard error; and $\theta_{\mathrm{W}}$, population mean mutation rate of Watterson's theta estimator. 
US-19 multilocus genotypes were found on tomato in North Carolina (48). In 2002 to 2007 the US-20 multilocus genotype was found in western North Carolina. A rapid displacement of the US20 and US-21 multilocus genotypes by US-22 was observed in 2009 on tomato in the eastern United States. Nucleotide diversity and the mean population mutation rate of the ras gene and introns were greater among tomato than potato isolates, and more haplotypes were observed in tomato than potato. The underlying genetic mechanisms of this more rapid displacement of genotypes on tomato needs further study

Our data indicate that isolates of the US-22 and US-23 genotypes are generally sensitive to mefenoxam. Additionally, isolates of the US-24 genotype are more sensitive to mefenoxam than are isolates of the US-8 genotype. The difference between US-8 and US-24 should be investigated further to determine whether mefenoxam might be useful to suppress late blight outbreaks caused by US-24. The reduced use of mefenoxam for late blight suppression in the United States has lessened selection pressure for mefenoxam-resistant strains. This situation is consistent with the situation in other locations-reduced usage has been associated with the recurrence of mefenoxam-sensitive strains. Such occurrences have been documented in locations that have very diverse populations (central Mexico) as well as in locations where the populations are asexual (Ireland) (13,29).

The results of this study have significant practical implication. Because populations of $P$. infestans in the United States appear to be still asexual and highly clonal, it is possible to use molecular markers on a small sample to identify the genotype of the pathogen in a field. SSR markers have great practical potential because they are PCR based and highly sensitive, and can provide data on multiple loci within a few days of receipt of a sample. Therefore, one can assess the genotype without isolating the pathogen into pure culture. We now know that US-22 and US-23 are sensitive to mefenoxam. SSR markers can be used to determine multilocus genotype quite rapidly. As long as these genotypes remain sensitive to mefenoxam, in the short term, if either of these genotypes is detected as the pathogen, growers could learn quickly whether mefenoxam might be useful. Markers specifically linked to loci associated with mefenoxam sensitivity in the pathogen also need to be developed.

An integrated warning system that informs home gardeners, organic and conventional growers, extension personnel, and research faculty has been developed to help prevent a pandemic such as occurred in 2009. The early-warning alert system was used in 2011 for much of the United States and phone- and email-based alerts of disease outbreaks were sent to users. The alert system can be found at www.USAblight.org. Suppliers of tomato transplants are now aware that transplants can be a source of inoculum and have taken steps to avert the possibility of distributing infected transplants over a wide area. These steps combined with rapid diagnostics for detection of the pathogen and knowledge of fungicide sensitivity should enable a much better-informed management strategy for late blight in the future.

\section{Acknowledgments}

This work was supported, in part, by a grant to J. Ristaino from the USDA NRI number 2006-55319-16550, an ARS CRIS to the Deahl lab, and Hatch funds provided to North Carolina State University, the University of Florida, and Cornell University. We thank S. Bost, T. Campbell, K. Everts, R. Donahoo, K. Deahl, W. Fry, M. Gallegly, A. Gevens, S. Goodwin, N. Gregory, B. Gugino, N. Gutmestead, D. Halterman, K. Ivors, T. Keinath, S. Johnson, M. McGrath, R. Mulrooney, M. Olanya, B. Platt, K. Rane, S. Rideout, P. Roberts, J. Ristaino, D. Schmale, G. Secor, G. Vallad, and S. Zhang for providing isolates that were characterized in this work.

\section{Literature Cited}

1. Anderson, P. K., Cunningham, A. A., Patel, N. G., Morales, F. J., Epstein, P. R., and Daszak, P. 2004. Emerging infectious diseases of plants: pathogen pollution, climate change and agrotechnology drivers. Trends Ecol. Evol. 19:535-544.

2. Andersson, B., Widmark, A.-K., Yuen, J. E., Nielsen, B., Ravnskov, S., Kessel, G. J. T., Evenhuis, A., Turkensteen, L. J., Hansen, J. G., Lehtinen, A., Hermansen, A., Brurberg, M.-B., and Nordskog, B. 2009. The role of oo- spores in the epidemiology of potato late blight. Acta Hortic. 834:61-68.

3. Aylor, D. L., Price E. W., and Carbone, I. 2006. SNAP: Combine and Map modules for multilocus population genetic analysis. Bioinformatics 22:1399-1401.

4. Birch, P. R. J., and Whisson, S. C. 2001. Phytophthora infestans enters the genomics era. Mol. Plant Pathol. 2:257-263.

5. Bourke, A. 1991. Potato late blight in Europe in 1845: the scientific controversy. Pages 12-24 in: Phytophthora. J. A. Lucas, R. C. Shattock, D. S. Shaw, and L. R. Cooke, eds. Cambridge University Press, New York.

6. Bourke, P. M. A. 1964. Emergence of potato blight, 1943-46. Nature 203:805-808.

7. Carter, D. A., Archer, S. A., Buck, K. W., Shaw, D. S., and Shattock, R. C. 1990. Restriction fragment length polymorphisms of mitochondrial DNA of Phytophthora infestans. Mycol. Res. 94:1123-1128.

8. Caten, C. E., and Jinks, J. L. 1968. Spontaneous variability of single isolates of Phytophthora infestans. I. Cultural variation. Can. J. Bot. 46:329348.

9. Chen, Y., and Roxby, R. 1996. Characterization of a Phytophthora infestans gene involved in vesicle transport. Gene 181:89-94.

10. Cooke, D. E. L., Lees, A. K., Hansen, J. G., Lassen, P., Andersson, B., and Bakonyi, J. 2007. EUCABLIGHT one year on: an update on the European blight population database. Pages 129-135 in: Proc. 10th Workshop for European Network Development of an Integrated Control Strategy of Potato Late Blight. H. T. A. M. Schepers, ed. PPO Spec. Rep. No. 12.

11. Deahl, K. L., DeMuth, S. P., Sinden, S. L., and Rivera-Pena, A. 1995. Identification of mating types and metalaxyl resistance in North American populations of Phytophthora infestans. Am. Potato. J. 72:35-49.

12. Deahl, K. L., Inglis, D. A., and DeMuth, S. P. 1993. Testing for resistance to metalaxyl in Phytophthora infestans isolates from northwestern Washington. Am. Potato J. 70:779-795.

13. Dowley, L. J., and E. O'Sullivan. 1985. Monitoring metalaxyl-resistant strains of Phytophthora infestans (Mont.) de Bary in Ireland. Pot. Res. 28:531-534.

14. Drenth, A, Goodwin, S. B., Fry, W. E., and Davidse, L. C. 1993. Genotypic diversity of Phytophthora infestans in the Netherlands revealed by DNA polymorphisms. Phytopathology 83:1087-1092.

15. Drenth, A., Tas, I. C. Q., and Govers, F. 1994. DNA fingerprinting uncovers a new sexually reproducing population of Phytophthora infestans in the Netherlands. Eur. J. Plant Pathol. 100:97-107.

16. Drenth, A., Turkensteen, L. J., and Govers, F. 1993. The occurrence of the A2 mating type of Phytophthora infestans in the Netherlands; significance and consequences. Neth. J. Plant Pathol. 99:57-67.

17. Elansky, S., Smirnov, A., Dyakov, Y., Dolgova, A., Filippov, A., Kozlovsky, B., Kozlovskaya, I., Russo, P., Smart, C., and Fry, W. E. 2001. Genotypic analysis of Russian isolates of Phytophthora infestans from the Moscow region, Siberia and Far East. J. Phytopathol. 149:605-611.

18. Forbes, G. A., Goodwin, S. B., Drenth, A., Oyarzun, P., Ordoñez, M. E., and Fry, W. E. 1998. A global marker database for Phytophthora infestans. Plant Dis. 82:811-818.

19. Fraser, D. E., Shoemaker, P. B., and Ristaino, J. B. 1999. Characterization of isolates of Phytophthora infestans from tomato and potato in North Carolina from 1993 to 1995. Plant Dis. 83:633-638.

20. Fry, W. E., Goodwin, S. B., Matuszak, J. M., Spielman, L. J., Milgroom, M G., and Drenth, A. 1992. Population genetics and intercontinental migrations of Phytophthora infestans. Annu. Rev. Phytopathol. 30:107-129.

21. Fry, W. E., Grunwald, N. J., Cooke, D. E. L., McLeod, A., Forbes, G. A. and Cao, K. 2009. Population genetics and population diversity of Phytophthora infestans. Pages 139-164 in: Oomycete Genetics and Genomics: Diversity, Interactions and Research Tools. K. Lamour and S. Kamoun, eds Wiley-Blackwell, Hoboken, NJ.

22. Gallegly, M. E., and Galindo, J. 1958. Mating types and oospores of Phytophthora infestans in nature in Mexico. Phytopathology 48:274-277.

23. Gómez-Alpizar, L., Carbone, I., and Ristaino, J. B. 2007. An Andean origin for Phytophthora infestans inferred from mitochondrial and nuclear gene genealogies. Proc. Natl. Acad. Sci. USA 104:3306-3311.

24. Goodwin, S. B., Drenth, A., and Fry, W. E. 1992. Cloning and genetic analyses of two highly polymorphic, moderately repetitive nuclear DNAs from Phytophthora infestans. Curr. Genet. 22:107-115.

25. Goodwin, S. B., Schneider, R. E., and Fry, W. E. 1995. Use of celluloseacetate electrophoresis for rapid identification of allozyme genotypes of Phytophthora infestans. Plant Dis. 79:1181-1185.

26. Goodwin, S. B., Smart, C. D., Sandrock, R. W., Deahl, K. L., Punja, Z. K., and Fry, W. E. 1998. Genetic change within populations of Phytophthora infestans in the United States and Canada during 1994 to 1996: role of migration and recombination. Phytopathology 88:939-949.

27. Goodwin, S. B., Sujkowski, L. S., Dyer, A. T., Fry, B. A., and Fry, W. E. 1995. Direct detection of gene flow and probable sexual reproduction of Phytophthora infestans in northern North America. Phytopathology 85:473479.

28. Griffith, G. W., and Shaw, D. S. 1998. Polymorphisms in Phytophthora infestans: four mitochondrial haplotypes are detected after PCR amplification of DNA from pure cultures or from host lesions. Appl. Environ. Microbiol. 64:4007-4014

29. Grünwald, N. J., Flier, W. G., Sturbaum, A. K., Garay-Serrano, E., van den 
Bosch, T. B. M., Smart, C. D., Matuszak, J. M., Lozoya-Saldana, H., Turkensteen, L. J., and Fry, W. E. 2001. Population structure of Phytophthora infestans in the Toluca Valley region of central Mexico. Phytopathology 91:882-890.

30. Gunderson, J. H., Elwood, H., Ingold, A., Kindle, K., and Sogin, M. L. 1987. Phylogenetic relationships between chlorophytes, chrysophytes, and oomycetes. Proc. Natl. Acad. Sci. USA 84:5823-5827.

31. Hall, T. A. 1999. BioEdit: a user-friendly biological sequence alignment editor and analysis program for Windows 95/98/NT. Nucleic Acids Symp. Ser. 41:95-98.

32. Haverkort, A. J., Boonekamp, P. M., Hutten, R., Jacobsen, E., Lotz, L. A. P., Kessel, G. J. T., Visser, R. G. F., and van der Vossen, E. A. G. 2008. Societal costs of late blight in potato and prospects of durable resistance through cisgenic modification. Pot. Res. 51:47-57.

33. Hu, C.-H., Perez, F. G., Donahoo, R., McCleod, A., Myers, K. L., Ivors, K. L., Roberts, P. D., Fry, W. E., Deahl, K. L., and Ristaino, J. B. 2010. Genetic structure of Phytophthora infestans population in eastern North America, 2002-2009. (Abstr.) Phytopathology 100:S52.

34. Ivors, K., and Louws, F. 2010. 2010 Foliar fungicide spray guide for tomatoes in North Carolina. http://www.ces.ncsu.edu/fletcher/programs/plant path/tomato-spray-guide/index.html

35. Knapova, G., and Gisi, U. 2002. Phenotypic and genotypic structure of Phytophthora infestans populations on potato and tomato in France and Switzerland. Plant Pathol. 51:641-553.

36. Lee, T. Y., Simko, I., and Fry, W. E. 2002. Genetic control of aggressiveness in Phytophthora infestans to tomato. Can. J. Plant Pathol. 24:471-480.

37. Lees, A. K., Wattier, R., Shaw, D. S., Sullivan, L., Williams, N. A., and Cooke, D. E. L. 2006. Novel microsatellite markers for the analysis of Phytophthora infestans populations. Plant Pathol. 55:311-319.

38. May, K. J., and Ristaino, J. B. 2004. Identify of the mtDNA haplotype(s) of Phytophthora infestans in historical specimens from the Irish potato famine. Mycol. Res. 108:471-479.
39. Mayton, H., Smart, C. D., Moravec, B. C., Mizubuti, E. S. G., Muldoon, A. E., and Fry, W. E. 2000. Oospore survival and pathogenicity of single oospore recombinant progeny from a cross involving the US-8 and US-17 lineages of Phytophthora infestans. Plant Dis. 84:1190-1196.

40. Moskin, J. 2009. Outbreak of fungus threatens tomato crop. In: New York Times. July, 17, 2009. http://www.nytimes.com/2009/07/18/nyregion/ 18tomatoes.html

41. National Oceanic and Atmospheric Administration. State of the Climate National Overview 2009. National Climatic Data Center, Asheville, NC.

42. Pennisi, E. 2010. Armed and dangerous. Science 327:804-805.

43. Price, E. W., and Carbone, I. 2005. SNAP: workbench management tool for evolutionary population genetic analysis. Bioinformatics 21:402-404.

44. Ristaino, J. B., Groves, C. T., and Parra, G. R. 2001. PCR amplification of the Irish potato famine pathogen from historic specimens. Nature 411:695697.

45. Schultz, D., Donahoo, R. S., Perez, F. G. M., Tejeda, S., Roberts, P. D., and Deahl, K. L. 2010. A survey of tomato and potato fields in Florida reveals unique genotypes of Phytophthora infestans between 2005 and 2007. HortScience 45:1064-1068.

46. Stone, A. 2009. Organic management of late blight of potato and tomato (Phytophthora infestans). http://www.extension.org/article/18361

47. Sujkowski, L. S., Goodwin, S. B., Dyer, A. T., and Fry, W. E. 1994. Increased genotypic diversity via migration and possible occurrence of sexual reproduction of Phytophthora infestans in Poland. Phytopathology 84:201207.

48. Wangsomboondee, T., Groves, C. T., Shoemaker, P. B., Cubeta, M. A., and Ristaino, J. B. 2002. Phytophthora infestans populations from tomato and potato in North Carolina differ in genetic diversity and structure. Phytopathology 92:1189-1195.

49. Zwankhuizen, M. J., Govers, F., and Zadoks, J. C. 2000. Inoculum sources and genotypic diversity of Phytophthora infestans in Southern Flevoland, the Netherlands. Eur. J. Plant Pathol. 106:667-680. 